\title{
Determination of Nonvolatile Organic Carbon in Aquifer Solids After Carbonate Removal by Sulfurous Acid
}

\author{
by G. Heron ${ }^{\text {, }}$, M. J. Barcelona ${ }^{b}$, M. L. Andersen ${ }^{a}$, and T. H. Christensen ${ }^{\text {a }}$
}

\begin{abstract}
The precise determination of total organic carbon (TOC) in aquifer materials is important in the estimation of retardation coefficients for organic compound transport. Commonly used methods for TOC determination after carbonate removal by acidification include: weight loss on ignition of solids at $550^{\circ} \mathrm{C}$, acid-dichromate oxidation, and combustion at $800-950^{\circ} \mathrm{C}$. Since carbonate carbon frequently is more abundant than organic carbon all TOC methods depend on efficient and complete carbonate removal prior to the TOC quantification step. A method for the determination of TOC in aquifer solids involving carbonate removal by $0.73 \mathrm{M}$ sulfurous acid and subsequent combustion at $800^{\circ} \mathrm{C}$ was tested on solids from three aquifers and on mineral standards. The carbon quantification by combustion and infrared detection of $\mathrm{CO}_{2}$ was accurate at solid organic carbon contents between 30 and $10,000 \mu \mathrm{gC} / \mathrm{g}$. The acid treatment added small amounts of carbon to the sample, and siderite removal was incomplete. For samples without siderite or dolomite, the accuracy of TOC determinations was enhanced by grinding the solids. Measurement of very low TOC contents (50-100 $\mu \mathrm{gC} / \mathrm{g})$ requires supplementary testing of grinding and acid treatment effects.
\end{abstract}

\section{Introduction}

Low concentration levels of particulate or solid-associated organic matter $(<1000 \mu \mathrm{gC} / \mathrm{g})$ may be quantitatively significant as sorbents for organic chemicals (Brusseau et al., 1991). Errors in determination of TOC on aquifer solids can lead to significant over- or underestimations of sorption and retardation coefficients based on the fraction of organic carbon and published partition coefficients. For TOC contents below $0.1 \%$, analytical errors on the order of $20 \%$ can lead to estimated retardation coefficients which vary a factor of 2 or more. Organic carbon in aquifer solids may also make up a major part of the aquifer reduction capacity, i.e., the resistance to changes in oxidationreduction potential on addition of an oxidant or electron accep-

\footnotetext{
${ }^{a}$ Institute of Environmental Science and Engineering, Groundwater Research Centre, Technical University of Denmark, Building 115, DK-2800 Lyngby, Denmark.

${ }^{\mathrm{b}}$ Department of Civil \& Environmental Engineering, The University of Michigan, 221 IST BLDG, Ann Arbor, Michigan 48 109-2099,
} USA. 1996.

Received April 1995, revised December 1995, accepted January tor (Barcelona and Holm, 1991; Heron and Christensen, 1995). However, the determination of such low levels of total organic carbon (TOC) is a major challenge due to possible contamination during analysis and interferences caused by incomplete removal of solid inorganic carbon (Powell et al., 1989; Ball et al., 1990; Caughey et al., 1995). These problems are common to all methods of organic carbon determination in geological materials, including methods based on weight loss on ignition at temperatures above $450^{\circ} \mathrm{C}$ (APHA, AWWA, WEF, 1992) and wet digestion of the solids by acid dichromate (Adams, 1990; Walkley, 1935). The above methods are not sensitive enough for organic carbon contents below $0.1 \%$ which is common in glaciofluvial environments. The more recent studies referred to above have employed high-temperature combustion methods. For TOC determinations on acid pretreated samples, dry combustion is superior to wet oxidation due to the incomplete oxidation of some organics by potassium persulfate or potassium dichromate (Ball et al., 1990). Dry combustion involves oxidation to $\mathrm{CO}_{2}\left(800-950^{\circ} \mathrm{C}\right)$ and detection by infrared or coulometric detectors.

In an aquifer, the total mass of solid carbon species is often orders of magnitude higher than the mass of dissolved carbon species. The majority of the solid organic carbon is humic materials (Aiken et al., 1985; Ball et al., 1990). Inorganic carbon 
contents may be dominant (e.g., in dolomitic or calcareous aquifers) or minor (e.g., in certain glaciofluvial deposits). In anaerobic aquifers or in reduced parts of contaminated aquifers, solid carbonates such as siderite $\left(\mathrm{FeCO}_{3}\right)$ and rhodochrosite $\left(\mathrm{MnCO}_{3}\right)$ may be present (Baedecker et al., 1993; Heron et al., 1994).

Determination of TOC in solids requires either the removal of the inorganic carbon prior to analysis or subtraction of the total inorganic carbon (TIC) from the total carbon (TC) of the sample. The latter method is inappropriate in most cases due to the inaccuracy of the measurement and the subtraction of two large numbers to yield a small TOC value (e.g., Krom and Berner, 1983). Thus, inorganic carbon removal followed by a total carbon determination seems to be the most plausible approach.

Carbonates are removed by acid treatment (Gibbs, 1977; Barker and Chatten, 1982; Powell et al., 1989; Ball et al., 1990). The major difficulties in removing inorganic carbon include (1) avoiding loss of extractable and volatile organic compounds, (2) avoiding addition of small amounts of carbon due to impurities in the chemicals used, and (3) ensuring complete carbonate removal.

Loss of extractable organic compounds may be avoided by analyzing the TC of the acid after inorganic carbon removal or by drying the sample after acid treatment without discarding the acid containing the extractable organics. The loss of volatile organics during acid treatment is best minimized by keeping the temperature moderate (e.g., $40^{\circ} \mathrm{C}$ : Caughey et al., 1995) or by trapping and quantifying volatile fractions during the acid treatment. The contribution of organic carbon in the acid should be determined by testing acid blanks for each set of samples.

Carbonate removal may be incomplete if sparingly soluble carbonate phases are present. Most of the reported methods have only been tested on calcite (Powell et al., 1989; Ball et al., 1990). The solubility and dissolution rates of siderite $\left(\mathrm{FeCO}_{3}\right)$, rhodochrosite $\left(\mathrm{MnCO}_{3}\right)$, and dolomite $\left[\mathrm{MgCa}\left(\mathrm{CO}_{3}\right)_{2}\right]$ in acid may be much lower than those of calcite (Al-Asam et al., 1990; Heron et al., 1994). Thus, methods traditionally used for carbonate removal may be inappropriate for aquifer solids containing such minerals. Another prerequisite for complete removal of the carbonate phase is that the acidity of the added acid exceeds the pH buffering capacity (alkalinity) of the sample. Carbonate removal from aquifer solids may be expressed by the overall reaction (e.g., $\mathrm{FeCO}_{3}$ ):

$$
\mathrm{FeCO}_{3}+2 \mathrm{H}^{+} \rightarrow \mathrm{Fe}^{2+}+\mathrm{CO}_{2}+\mathrm{H}_{2} \mathrm{O}
$$

where removal of 1 mole of carbonate requires 2 moles of protons (1). A carbonate content of $1 \% \mathrm{w} / \mathrm{w}(10 \mathrm{mgC} / \mathrm{g})$ in a $1 \mathrm{~g}$ sample requires the addition of $1.7 \mathrm{mmol} \mathrm{H}^{+}$. For example, if $1 \mathrm{~g}$ of solid is treated by $0.73 \mathrm{M} \mathrm{H}_{2} \mathrm{SO}_{3}$ (as suggested by Gibbs, 1977 , and Caughey et al., 1995), at least $1.3 \mathrm{ml}$ of the acid is required. Considering the TIC ranges found in aquifers and the low solid/acid ratio typically used, this level of acid addition should normally be sufficient.

Potentially, large amounts of $\mathrm{SO}_{2}$ or $\mathrm{SO}_{3}$ produced from solid sulfur in the high-temperature combustion step for TOC determination may interfere with the infrared detection of carbon. Acid treatment of solids may, in some cases, add sulfur to the sample (that is, if sulfuric or sulfurous acid is used). The potential interference of sulfur added to the sample on the TOC determination should be evaluated in each case.
In this study, nonvolatile TOC determination by treatment with $0.73 \mathrm{M} \mathrm{H}_{2} \mathrm{SO}_{3}$ for carbonate removal, followed by dry combustion, was tested. The carbonate removal efficiency, possible interferences, the effect of sample heterogeneity, and the potential loss of organic matter during acid treatment were assessed. Landfill leachate contaminated as well as uncontaminated aquifer solid samples from three different geologic settings were analyzed.

\section{Materials and Methods}

Aquifer solids were sampled as intact cores in aluminum or PVC tubes ( $5 \mathrm{~cm}$ diameter), transferred to prebaked pyrex beakers and dried at $105^{\circ} \mathrm{C}$ overnight. Sample splits were ground in a stainless steel mill. Organic carbon-poor mineral sand was prepared by baking micaceous sand (Tertiary deposit, predominantly quartz from Grindsted, Denmark) at $550^{\circ} \mathrm{C}$ for $72 \mathrm{hrs}$. Sample splits for analysis were selected by hand using a spoon, and a relatively large sample size $(1 \mathrm{~g})$ compared to other studies was chosen to compensate for not using an automatic sample splitter.

For carbonate removal, $1.00 \mathrm{~g}$ of dry solid was treated either repeatedly by $2 \mathrm{ml}$ or once by $5 \mathrm{ml}$ of $0.73 \mathrm{M} \mathrm{H}_{2} \mathrm{SO}_{3}$ in a glass vessel for $24 \mathrm{hr}$ at $40^{\circ} \mathrm{C}$. After the final addition of $\mathrm{H}_{2} \mathrm{SO}_{3}$, the samples were dried at $105^{\circ} \mathrm{C}$ to constant weight and transferred to a porous combustion vial (Prod. 529-036; LECO Corp., MI), No acid was discarded in order to prevent loss of organic matter dissolved during the treatment. Catalysts (Tin Metal Accelerator Ar 076, AlphaCel Tungsten AR 027; Alpha Resources Inc, MI) were added and the sample was combusted in an oxygen atmosphere at $800^{\circ} \mathrm{C}$ in a LECO CS-225 Carbon and Sulfur Analyzer (LECO Corp., MI). The instrument was equipped with an infrared $\mathrm{CO}_{2}$ detector calibrated by combustion of standard steel rings (LECO Prod. 501-500 series) following the vendor's procedure. Results were recorded as microgram carbon per gram dry weight of sample ( $\mu \mathrm{gC} / \mathrm{gdw})$. For some illustration purposes, the total carbon mass detected, equal to the sample weight times the TOC concentration, was used (Table 1, 3, and Figure 1).

Commercial humic acid (sodium salt, technical quality; Aldrich Chemicals, Germany) was used for these experiments without pretreatment. The carbon content of the humic acid was determined by elemental analysis (CHN Elemental Analyzer, Carlo Erba EA 1108) after drying in a vacuum oven. A stock solution $(0.41 \mathrm{mgC} / \mathrm{l})$ of humic acid was prepared in deionized water, and precise amounts pipetted into the sandy samples or directly into the combustion cups. $\mathrm{CaSO}_{4} \cdot 2 \mathrm{H}_{2} \mathrm{O}$ (Merck 2161), $\mathrm{MnCO}_{3}$ (Prod. 29136; BDH Chemicals, UK), $\mathrm{FeSO}_{4} \cdot 7 \mathrm{H}_{2} \mathrm{O}$ (Merck 3965), and $\mathrm{CaCO}_{3}$ (Merck 2066) were used as reagent grade solids. Natural pyrite $\left(\mathrm{FeS}_{2}\right.$, purity $93 \%$ ) from Chessy, France was ground to a particle size $<74 \mu \mathrm{m}$. Siderite $\left(\mathrm{FeCO}_{3}\right.$, purity about $92 \%$ ) from Greenland was ground to a particle size $<250 \mu \mathrm{m}$. Dried standard minerals were added directly into the combustion cups or into pyrex beakers for acid treatment.

\section{Results and Discussion \\ Linearity of Carbon Determination by Combustion}

The accuracy of the carbon determination is illustrated by the mass of carbon detected during combustion of a sample, as a function of the amount of carbon added to the combustion cups (Figure 1). The linear range of carbon determination by dry combustion spanned from 20 to $10,000 \mu \mathrm{gC}$ in the combustion cup when only standard steel rings were added. The average TC 
Table 1. Results for Evaluation of Possible Interferences on TOC Determinations by $\mathrm{CaSO}_{4}, \mathrm{FeSO}_{4}$, and $\mathrm{FeS}_{2}$

\begin{tabular}{|c|c|c|}
\hline Sample & $\begin{array}{c}\text { Measured } T C \\
\mu g C\end{array}$ & $\begin{array}{l}\text { Standard deviation } \\
\mu g C\end{array}$ \\
\hline Blank (only combustion cup + catalysts) & 18 & 1.6 \\
\hline $\begin{array}{l}10 \mathrm{mg} \mathrm{CaSO}_{4} \\
100 \mathrm{mg} \mathrm{CaSO}_{4} \\
1000 \mathrm{mg} \mathrm{CaSO}_{4}\end{array}$ & $\begin{array}{l}20 \\
22 \\
53\end{array}$ & $\begin{array}{l}13 \\
1.3 \\
9\end{array}$ \\
\hline $\begin{array}{l}1.0 \mathrm{~g} \text { micaceous sand } \\
1.0 \mathrm{~g} \text { micaceous sand }+10 \mathrm{mg} \mathrm{FeSO}_{4} \\
1.0 \mathrm{~g} \text { micaceous sand }+10 \mathrm{mg} \mathrm{FeS}\end{array}$ & $\begin{array}{l}100 \\
102 \\
111\end{array}$ & $\begin{array}{l}3.5 \\
10 \\
7\end{array}$ \\
\hline
\end{tabular}

(Values are calculated from triplicates, and given as total $\mu \mathrm{g} \mathrm{C}$ detected during combustion. Samples were analyzed without acid treatment.)

count for 6 blanks (only catalysts added to the cup) was $18 \mu \mathrm{gC}$ (stdev $=2.7 \mu \mathrm{gC}$ ). This number was subtracted from the measured values reported later, except in Table 1. Based on this, the detection limit of the combustion step was estimated to be 30 $\mu \mathrm{gC} / \mathrm{gdw}(0.003 \%$ by weight) for a $1 \mathrm{~g}$ sample (the value of the blank plus three times the standard deviation). Humic acid carbon was measured in the range from 25 to $1800 \mu \mathrm{gC}$ (Figure
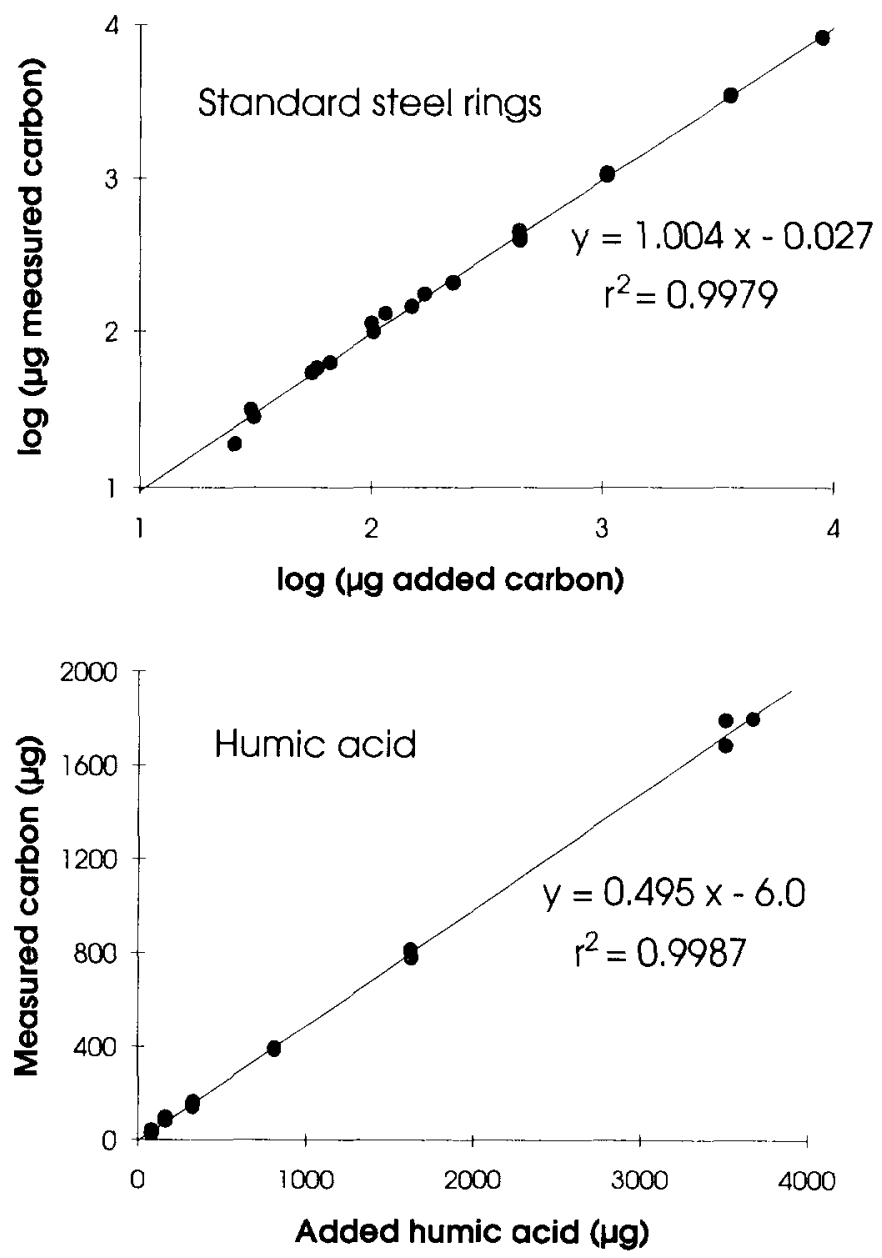

Fig. 1. Linearity of the carbon determination on standard steel rings (upper figure) and recovery of carbon from added humic acid (lower figure). The carbon determined for blanks (18 $\mu \mathrm{g} \mathrm{C}$; supposedly impurity in catalysts and cups) was subtracted from all measured values. The regression line for humic acid shows $49.5 \%$ carbon.
1). The estimated carbon percentage (49.5\%) based on combustion of dry humic acid is close to the value determined by elemental analysis $(47.8 \%)$, showing that humic acid carbon is determined satisfactorily in the combustion step.

\section{Interference on Carbon Determination by Combustion}

High sulfur contents in a sample could potentially lead to interference due to $\mathrm{SO}_{3}$ production in the combustion step. However, the effect of potential interferences from sulfurcontaining minerals such as $\mathrm{CaSO}_{4}, \mathrm{FeSO}_{4}$ and $\mathrm{FeS}_{2}$ on the carbon determination were found to be negligible for contents below $10 \%=0.1 \mathrm{~g} \mathrm{~S} / \mathrm{g}$ sample (Table 1). Therefore, accumulation of solid sulfates during acid treatment or the occurrence of elevated pyrite contents in reduced aquifers is apparently not critical to the TOC determination.

\section{Tested Aquifer Solids}

The aquifer solids used in this study are listed in Table 2. The Vejen and Grindsted samples were relatively low in inorganic carbon content (supposedly within the range of the TOC content). The solid samples from landfill leachate contaminated aquifers were of interest since they could contain authigenic carbonates produced during redox buffering reactions involving the oxidation of organic matter coupled to $\mathrm{Fe}$ (III)-reduction (Baedecker et al., 1993; Heron, 1994).

\section{Inorganic Carbon Removal Efficiency}

The addition of pure $\mathrm{CaCO}_{3}, \mathrm{MnCO}_{3}$, and $\mathrm{FeCO}_{3}$ to a contaminated sample from the $\mathrm{Fe}$ (III)-reducing zone of the Vejen landfill leachate plume slightly increased the measured TOC level (Table 3). However, the relatively large standard deviations on triplicate samples (despite the large sample sizes) limit quantitative conclusions on the degree of carbonate removal. Therefore, $\mathrm{FeCO}_{3}$ was added to the fine-grained, homogeneous micaceous sand from the pristine part of the Grindsted aquifer (Table 4). Despite the fact that excess acid was added [6 $\mathrm{ml} 0.73 \mathrm{M} \mathrm{H}_{2} \mathrm{SO}_{3}$ which may stoichiometrically dissolve 46,000 $\mu \mathrm{gC}$ according to equation (1)], the removal of siderite was incomplete, ranging from 21 to $86 \%$ of the added carbon. This agrees with previous observations of very slow siderite dissolution even in concentrated $\mathrm{H}_{3} \mathrm{PO}_{4}$ at $50^{\circ} \mathrm{C}$ (Al-Aasm et al., 1990). We conclude that crystalline siderite is not removed satisfactorily by $0.73 \mathrm{M} \mathrm{H}_{2} \mathrm{SO}_{3}$ and that the presence of $\mathrm{Fe}$ (II) carbonates in reduced aquifer solids may bias the determination of TOC by this method. 
Table 2. Characteristics of Aquifer Solids Analyzed in This Study

(No Value is Given for TOC in the Villa Farm Solids, Since the TOC Could Not be Determined)

\begin{tabular}{|c|c|c|c|c|c|c|}
\hline & Aquifer type & Grain size & $\begin{array}{l}\text { TOC range } \\
\mu g C / g d w^{\prime}\end{array}$ & $\begin{array}{c}\text { TIC content } \\
\mu g C / g d w\end{array}$ & $\begin{array}{l}\text { Suspected } \\
\text { TIC species }\end{array}$ & Other species \\
\hline Vejen, landfill plume & $\begin{array}{l}\text { Glacio-fluvial } \\
\text { quartz }\end{array}$ & $\begin{array}{l}\text { Medium to } \\
\text { coarse sand }\end{array}$ & $200-1200$ & $<200$ & no & Pyrite \\
\hline Grindsted, pristine & $\begin{array}{l}\text { Micaceous } \\
\text { quartz }\end{array}$ & Fine sand & $50-200$ & $<100$ & no & no \\
\hline $\begin{array}{l}\text { Grindsted, landfill } \\
\text { plume }\end{array}$ & $\begin{array}{l}\text { Micaceous } \\
\text { quartz }\end{array}$ & Fine sand & $90-400$ & $\mathrm{NA}^{2}$ & $\begin{array}{c}\mathrm{FeCO}_{3} \\
\mathrm{MnCO}_{3}\end{array}$ & Sulfides \\
\hline $\begin{array}{l}\text { Grindsted, landfill } \\
\text { plume }\end{array}$ & $\begin{array}{l}\text { Glacio-fluvial } \\
\text { quartz }\end{array}$ & $\begin{array}{l}\text { Medium to } \\
\text { coarse sand }\end{array}$ & $100-3500$ & NA & $\begin{array}{l}\mathrm{FeCO}_{3} \\
\mathrm{MnCO}_{3}\end{array}$ & Sulfides \\
\hline $\begin{array}{l}\text { Villa Farm, waste } \\
\text { disposal plume }\end{array}$ & $\begin{array}{c}\text { Lacustrine } \\
\text { quartz }+ \text { calcite }+ \\
\text { dolomite }\end{array}$ & $\begin{array}{l}\text { Medium to } \\
\text { coarse sand }\end{array}$ & NA & $\begin{array}{l}\text { very high } \\
>10000\end{array}$ & $\begin{array}{c}\mathrm{CaCO}_{3} \\
\mathrm{FeCO}_{3} \\
\mathrm{MgCa}\left(\mathrm{CO}_{3}\right)_{2}\end{array}$ & Pyrite \\
\hline
\end{tabular}

${ }^{1} \mathrm{gdw}=$ gram dry weight.

${ }^{2} \mathrm{NA}=$ Not Analyzed (no value determined).

Table 3. Total Carbon Amounts Determined by Combustion of Solids From the Fe(III)-Reducing Zone of the Vejen Landfill Leachate Plume (Heron and Christensen, 1995) With and Without Addition of Carbonates

\begin{tabular}{lccc}
\hline Addition & Added $\mu g C$ & $\begin{array}{c}\text { Mean TOC } \\
\mu g C\end{array}$ & $\begin{array}{c}\text { Standard deviation } \\
\mu g C\end{array}$ \\
\hline None & - & 287 & 81 \\
$\mathrm{FeCO}_{3}$ & 830 & 294 & 44 \\
$\mathrm{MnCO}_{3}$ & 840 & 330 & 72 \\
$\mathrm{CaCO}_{3}$ & 1000 & 328 & 117
\end{tabular}

(Triplicate solid samples $(1.0 \mathrm{gdw})$ were treated by addition of 3 times $2 \mathrm{ml} 0.73 \mathrm{M} \mathrm{H}_{2} \mathrm{SO}_{3}$ )

Table 4. Removal of Crystalline Siderite by 3 Times Treatment by $2 \mathrm{ml}$ of Sulfurous Acid

\begin{tabular}{lc}
\hline Added $\mathrm{FeCO}_{3}$ & $\begin{array}{c}\text { \% Carbonate } \\
\text { removal }\end{array}$ \\
\hline $10 \mathrm{mg}$ & 86 \\
$50 \mathrm{mg}$ & 62 \\
$200 \mathrm{mg}$ & 21 \\
\hline
\end{tabular}

(Values are calculated from triplicates.)

Table 5. TIC Interference on TOC Determination in Carbonate-Rich Villa Farm Aquifer Solids

\begin{tabular}{ccc}
\hline Acid addition & $\begin{array}{c}\text { Mean TOC } \\
\mu g C / g d w\end{array}$ & $\begin{array}{c}\text { Standard deviation } \\
\mu g C / g d w\end{array}$ \\
\hline $1 \times 2 \mathrm{ml} \mathrm{H}_{2} \mathrm{SO}_{3}$ & 11930 & 1403 \\
$2 \times 2 \mathrm{ml} \mathrm{H}_{2} \mathrm{SO}_{3}$ & 6750 & 434 \\
$3 \times 2 \mathrm{ml} \mathrm{H}_{2} \mathrm{SO}_{3}$ & 3560 & 781 \\
$1 \times 5 \mathrm{ml} \mathrm{H}_{2} \mathrm{SO}_{3}$ & 3110 & 402 \\
\hline
\end{tabular}

(The true TOC was not determined.)
Based on these results, the incomplete carbonate removal from the calcite- and dolomite-bearing Villa Farm samples was expected (Table 5). The aquifer is interbedded between two relatively impermeable clay layers and reducing conditions exist (Christensen et al., 1994; Heron, 1994). Large amounts of reduced $\mathrm{Fe}$ (II) were extracted from the sediments by $0.5 \mathrm{M} \mathrm{HCl}$ (Christensen et al., 1994) indicating that siderite might be present (according to Heron et al., 1994). After three successive additions of $2 \mathrm{ml} \mathrm{H} \mathrm{H}_{2} \mathrm{SO}_{3}$ we concluded that the TOC could not be determined without further testing (Table 5).

\section{Humic Acid Carbon Recovery}

In aquifer solids without siderite, quantitative TOC determinations at extremely low levels (i.e. $<50 \mu \mathrm{g} / \mathrm{gdw}$ ) may be warranted. Humic acid carbon additions to organic carbon-poor (baked) mineral quartz sand from Grindsted were recovered satisfactorily (Table 6). Humic acid added in the range of 40 to $821 \mu \mathrm{gC}$ to mineral sand was adequately recovered $(88-127 \%)$. after acid treatment, the recovery was lower (56-93\%), indicating that part of the organic matter was lost during acid treatment. The percent loss was observed to increase with decreasing humic acid carbon concentrations (Table 6). This loss was somewhat surprising since humic acids have been considered nonvolatile at low pH (Davis, 1982; Schnitzer, 1986). We speculate that dissolution and volatilization of inorganic carbon impurities in the humic acid or adsorption onto the glassware during acid treatment could explain this loss, but the reason remains unclear.

\section{Acid Impurity Testing}

The mineral sand sample $(1.0 \mathrm{~g})$ was observed to gain about $34 \mu \mathrm{g}$ carbon (standard deviation $12 \mu \mathrm{gC}$ ) during the acid treatment (Table 6). This carbon increase could be explained by carbon impurities in the acid. Ball et al. (1990) observed a lower $(9 \mu \mathrm{gC})$ TC increase during treatment with $\mathrm{H}_{3} \mathrm{PO}_{4}$. As stated by Caughey et al. (1995), it is crucial to test every lot of acid by running methods blanks, since the carbon content of commercial acids may vary. 
Table 6. Recovery of Humic Acid Carbon as TOC With and Without Acid Treatment (3 Times $2 \mathrm{ml} \mathrm{H}_{2} \mathrm{SO}_{3}$ )

\begin{tabular}{|c|c|c|c|c|c|c|}
\hline \multirow[b]{2}{*}{$\begin{array}{c}\text { Humic acid } \\
\text { added } \\
\mu g C\end{array}$} & \multicolumn{3}{|c|}{ Treated with $3 \times 2 \mathrm{ml} \mathrm{H}_{2} \mathrm{SO}_{3}$} & \multicolumn{3}{|c|}{ Untreated } \\
\hline & $\begin{array}{c}\text { Mean TOC } \\
\mu g C / g d w\end{array}$ & $\begin{array}{l}\text { Standard } \\
\text { deviation } \\
\mu g c / g d w\end{array}$ & $\begin{array}{c}\text { Humic acid } \\
\text { recovery } \\
\%\end{array}$ & $\begin{array}{c}\text { Mean TOC } \\
\mu g C / g d w\end{array}$ & $\begin{array}{l}\text { Standard } \\
\text { deviation } \\
\mu g C / g d w\end{array}$ & $\begin{array}{c}\text { Humic acid } \\
\text { recovery } \\
\%\end{array}$ \\
\hline 0 & 79 & 9 & - & 45 & 8 & - \\
\hline 41 & 106 & 4 & 66 & 97 & 3 & 127 \\
\hline 82 & 125 & 4 & 56 & 138 & 1 & 113 \\
\hline 164 & 193 & 8 & 70 & 238 & 30 & 114 \\
\hline 411 & 411 & 18 & 81 & 406 & 15 & 88 \\
\hline 821 & 844 & 39 & 93 & 822 & 31 & 93 \\
\hline
\end{tabular}

[Humic acid carbon was added to 1.0 gram of mineral sand from a stock solution $(0.41 \mathrm{mgC} / 1)$.]

Table 7. Heterogeneity and Grain-Size Effect on the Precision of Triplicate TC Determinations on Aquifer Solids

\begin{tabular}{|c|c|c|c|c|c|c|}
\hline & \multicolumn{2}{|c|}{ Vejen contaminated } & \multicolumn{3}{|c|}{ Grindsted } & \multirow{2}{*}{$\begin{array}{c}\text { Villa Farm } \\
\text { Quaternary } \\
\text { contaminatea }\end{array}$} \\
\hline & No grinding & Ground & $\begin{array}{l}\text { Micaceous } \\
\text { pristine }\end{array}$ & $\begin{array}{c}\text { Micaceous } \\
\text { contaminated }\end{array}$ & $\begin{array}{c}\text { Quaternary } \\
\text { contaminated }\end{array}$ & \\
\hline Number of samples & 9 & 12 & 5 & 18 & 5 & 12 \\
\hline TC range $(\mu \mathrm{gC} / \mathrm{gdw})$ & $200-900$ & $300-3130$ & $90-110$ & $90-370$ & $140-3330$ & $500-13400$ \\
\hline Mean coeff. of variance & 0.177 & 0.049 & 0.034 & 0.156 & 0.096 & 0.149 \\
\hline
\end{tabular}

(The coefficient of variance is the standard deviation divided by the average TC concentration.)

\section{Heterogeneity Effects}

The effect of aquifer solid heterogeneity on the reproducibility of TOC and TC determinations was studied for a total of 61 samples from three different aquifers (Table 7). Precision is expressed as the mean coefficient of variance (standard deviation divided by the mean carbon concentration). A clear tendency towards increasing heterogeneity with increasing grain size was observed. This is in agreement with Ball et al. (1990) who found increasing standard deviation with increasing grain size fractions of Borden aquifer solids. These results may be explained by increased solid heterogeneity with grain size and less precise subsample retrieval.

Grinding of the medium to coarse-grained Vejen solids decreased the coefficient of variance from 0.18 to 0.049 (Table 7). However, in some cases grinding may not be feasible. If wet samples are to be analyzed in order to prevent oxidation of the sample or not to lose volatiles, grinding is impractical. For samples with very low TOC, the addition of small amounts of carbon during grinding (10-50 $\mu \mathrm{gC}$ per sample; Ball et al., 1990) may also introduce bias into the TOC determinations.

A tendency towards higher carbon variability for contaminated samples was observed (Table 7). This may be explained by the uneven distribution of microorganisms in contaminated aquifers, leading to small-scale variability in solid contents of organic matter and carbonates.

\section{Summary}

TOC determinations by sulfurous acid acidification and combustion may be successful on aquifer solid samples with a wide range of organic carbon contents, if the solids are low in siderite, $\mathrm{FeCO}_{3}$ and other hardly soluble carbonates. At low concentrations of organic carbon the potential loss of humic acid carbon during carbonate removal by sulfurous acid may lead to underestimation of the TOC. Method blanks on carbon-free sand should be run, since both commercial acids, cups, and catalysts for combustion may contain small amounts of carbon (10-50 $\mu \mathrm{gC}$ per sample). Detection limits of $30-50 \mu \mathrm{gC} / \mathrm{g}$ could be reached. The potential method interferences from sulfur species on the TOC determination were found to be negligible. For carbonate-rich aquifer solids containing siderite or dolomite, we recommend the use of alternative carbonate-removing agents.

\section{Acknowledgments}

The authors would like to thank Christian Gron (Institute of Applied Geology, Technical University of Denmark) and Jørn K. Pedersen (Institute of Hydrodynamics and Hydraulic Engineering, Technical University of Denmark) for helpful suggestions and ideas. The comments of three anonymous reviewers are very much appreciated.

\section{References}

Adams, V. D. 1990. Organic carbon in soils. Dichromate method. Section 5.6 in: Water and Wastewater Examination Manual. Lewis Publishers, Chelsea, MI. 249 pp.

Aiken, G. R., D. M. McKnight, R. C. Wershaw, and P. MacCarthy. 1985. Humic Substances in Soil, Sediment and Water: Geochemistry, Isolation and Characterization. John Wiley, NY. 743 pp.

Al-Aasm, I. S., B. E. Taylor, and B. South. 1990. Stable isotope analyses of multiple carbonate samples using selective acid extraction. Chemical Geology. v. 80, pp. 119-125.

American Public Health Association, American Water Works Associ- 
ation, and Water Environment Federation. 1992. Standard Methods for the Examination of Water and Wastewater. Part $2540 \mathrm{E}-$ Fixed and volatile solids ignited at $500^{\circ} \mathrm{C}$. American Public Health Assoc., Washington, DC. pp. 2-57.

Baedecker, M. J., I. M. Cozzarelli, R. P. Eganhouse, D. I. Siegel, and P. C. Bennett. 1993. Crude oil in a shallow sand and gravel aqufer. III. Biogeochemical reactions and mass balance modeling in anoxic groundwater. Applied Geochemistry. v. 8, pp. 569-586.

Ball, W. P., C. Buehler, T. C. Harmon, D. M. Mackay, and P. V. Roberts. 1990. Characterization of a sandy aquifer material at the grain scale. Journal of Contaminant Hydrology. v. 5, pp. 253-295.

Barcelona, M. J. and T. R. Holm. 1991. Oxidation-reduction capacities of aquifer solids. Environmental Science and Technology. v. $25, \mathrm{pp} .1565-1572$.

Barker, J. F. and S. Chatten. 1982. A technique for determining low concentrations of total carbonate in geologic materials. Chemical Geology. v. 36, pp. 317-323.

Brusseau, M. L., T. Larsen, and T. H. Christensen. 1991. Rate-limited sorption and nonequilibrium transport of organic chemicals in low organic carbon aquifer materials. Water Resources Research. v. 27, pp. 1137-1145.

Caughey, M. E., M. J. Barcelona, R. M. Powell, R. A. Cahill, C. Gr $\phi$ n, D. Lawrenz, and L. Meschi. 1995. Interlaboratory evaluation of a method for determining TOC in aquifer materials. Environmental Geology. v. 26, pp. 211-219.

Christensen, T. H., P. L. Bjerg, G. Heron, G. M. Williams, J.J.W. Higgo, A.C.M. Bourg, and R. S. Altman. 1994. Factors controlling the migration of priority pollutants in landfill pollution plumes. Final report, contract STEP CT90069, Commission of the European Communities.

Davis, J. A. 1982. Adsorption of natural dissolved organic matter at the oxide/water interface. Geochimica et Cosmochimica Acta. v. 46 , pp. 139-149.
Gibbs, R. J. 1977. Effects of temperature and time and the oxidation agent used in organic carbon and nitrogen analyses of sediments and dissolved organic material. Journal of Sedimentary Petrology. v. 47 , pp. $547-550$.

Heron, G. 1994. Redox buffering in landfill leachate contaminated aquifers. Ph.D. thesis, Institute of Environmental Science and Engineering, Technical University of Denmark.

Heron, G., C. Crouzet, A.C.M. Bourg, and T. H. Christensen. 1994. Speciation of $\mathrm{Fe}$ (II) and $\mathrm{Fe}$ (III) in contaminated sediments using chemical extraction techniques. Environmental Science and Technology. v. 28, pp. 1698-1705.

Heron, G. and T. H. Christensen. 1995. Impact of sediment bound iron on redox buffering in a landfill leachate polluted aquifer (Vejen, Denmark). Environmental Science and Technology. v. 29, pp. 187-192.

Krom, M. D. and R. A. Berner. 1983. A rapid method for the determination of organic and carbonate carbon in geological samples. Journal of Sedimentary Petrology. v. 53, pp. 660-663.

Powell, R. M., R. W. Callaway, J. T. Michalowski, S. A. Vandegrift, M. V. White, D. H. Kampbell, B. E. Bledsoe, and J. T. Wilson. 1988. Comparison of methods to determine oxygen demand for bioremediation of a fuel contaminated aquifer. International Journal on Environmental Analytical Chemistry. v. 34, pp. 253-263.

Powell, R. M., B. E. Bledsoe, G. P. Curtis, and R. L. Johnson. 1989. Interlaboratory methods comparison for the total organic carbon analysis of aquifer materials. Environmental Science and Technology. v. 23, pp. 1246-1249.

Schnitzer, M. 1986. Binding of humic substances by soil mineral colloids. In: Interactions of Soil Minerals with Natural Organics and Microbes. SSSA. Special Publication No. 17. Soil Science Society of America, Madison, WI. pp. 77-101.

Walkley, A. 1935. An examination of the methods for determining organic carbon and nitrogen in soils. Journal of Agronomy and Science. v. 25, pp. 598-609. 